\title{
The Control of Diabetes in Summer Campers, with Special Reference to Acetone Bodies*
}

\author{
H. K. ÅKERBLom \\ The Children's Hospital, University of Helsinki, Helsinki, Finland
}

Received: August 30, 1968

Summary. The present work was done to study the effect of camp life on the control of juvenile diabetes. Particular attention was paid to the role of exercise in the treatment of diabetes. Diurnal variations of blood glucose and acetone bodies, as well as those of glucosuria and ketonuria were recorded. Nine campers, aged 8-13 years, wero studied during a two week period. All diabetics were considered labile or hyperlabile. After an initial control period the campers had plenty of exercise daily. Diurnal blood glucose levels and glucosuria did not improve during the camp, whereas the concentrations of blood acetone bodies decreased. In particular this was true for morning hyperketonaemia. Judged from this, the diabetic control improved during the camp. However, the overall control of diabetes did not become good. The roles of insulin, diet and exereise in the control of juvenile diabetics are discussed.

Contrôle du diabète chez des campeurs d'été, avec référence spéciale aux corps cétoniques

Résumé. Le présent travail a été effectué pour étudier l'effet de la vie de camp sur le contrôle du diabète juvénile. Une attention particulière a été apportée au rôle de l'exercice dans le traitement du diabète. Les variations au cours de la journée du glucose et des corps cétoniques dans le sang, aussi bien que de la glucosurie et de la cétonurie ont été enregistrées. Le cas de neuf campours de 8 à 13 ans a été étudié pendant une période de deux semaines. Tous les diabétiques étaient considérés comme labiles ou hyperlabiles. Après une première période témoin les campeurs ont fait chaque jour beaucoup d'exercices. Les taux de glycémie au cours de la journée et la glucosurie n'ont subi aucune amélioration durant le camp, tandis que la concentration du sang en corps cétoniques a diminué. Ceci a été remarqué en particulier pour l'hyper- cétonémie matinale. Il y a eu une amélioration du contrôle du diabète pendant le camp, si on en juge par la présence des corps cétoniques dans le sang. Cependant le contrôle général du diabète sucré ne devint pas bon. Le rôle de l'insuline, d'un régime et de certains exercices dans le contrôle des diabétiques juvéniles est discuté.

Die Stoffwechselführung des Diabetes unter Ferienlagerbedingungen mit besonderer Berücksichtigung der Acetonkörper

Zusammenfassung. Die vorliegende Arbeit wurde durchgeführt, um die Stoffwechselführung des juvenilen Diabetes unter den Bedingungen eines Ferienlagers zu untersuchen. Besondere Berücksichtigung fand die $\mathrm{Be}-$ deutung der körperlichen Bewegung für die Behandlung des Diabetes mellitus. - Es wurden Blutzucker- und Blutaceton-Tagesprofile, sowie die Glucosurie und Acetonurie registriert. Die Untersuchungen erfolgten an neun 8-13jährigen Teilnehmern des Ferienlagers über einen Zeitraum von zwei Wochen. Der Diabetes wurde als labil oder hyperlabil angesehen. Nach einer initialen Anpassungsperiode wurde jeden Tag ausgiebig Muskelarbeit geleistet. Darunter kam es zu keiner Verbesserung der Blutzuckertagesprofile oder der Zuckerausscheidung; die Acetonkörperspiegel im Blut fielen jedoch ab, und zwar besonders früh morgens. Danach zu urteilen, verbesserte sich zwar die Stoffwechsellage, die Gesamteinstellung blieb jedoch im wesentlichen unbeeinfußt. Die Bedeutung von Insulin, Diät und Muskelarbeit für dio Stoffwechselführung des juvenilen Diabetes werden diskutiert.

Key-words: Juvenile diabetes, summer camp, exercise, diabetic control, blood glucose, blood acetone bodies, glucosuria, ketonuria.
Summer camps for diabetic children have become an established and faroured activity in many countries. The camp offers opportunity for education, attaining of self-confidence, and recreation for the diabetic. The increased carbohydrate tolerance of diabetic children during the camp, as reflected in a smaller insulin requirement, is a well-known phenomenon. But reports on the influence of a summer camp on the control of diabetes are infrequent, when the occurence of acetone bodies is taken as one criterion. HANDELSMAN and co-workers (1961) considered exercise a potent treatment of asymptomatic ketonuria, based on experience from an one month-long camp for diabetic children.

The present study was undertaken to look into the effect of camp life on the control of diabetes during a two week period, especially with attention to the role

\footnotetext{
* Supported by Nordisk Insulinfond.
}

of exercise in the treatment of childhood diabetes, and to the levels of acetone bodies in blood and urine as additional indices of the diabetic control.

\section{Patients and Methods}

The study was done in June 1966 at the camp of the Finnish Diabetes Association in Aitolahti, Tampere. Nine boys participated in the study. The criteria in the selection were capability to co-operate and absence of signs of other diseases than diabetes. Seven campers received Lente insulin once daily, and two boys the biphasic Rapitard insulin twice daily. The insulin dosage of three cases was lowered during the camp by two units (in each case less than 10\%). Two boys left for home on the tenth eamp day. Table 1 provides a summary of clinical data.

The assessment of the diabetic state was based on information given by the referring physicians. Seven 
diabetics were considered labile because of moderate or excessive glucosuria and intermittent ketonuria. Two diabetics had in addition hypoglycaemic reactions in their history, and these cases were regarded as hyperlabile. The camp meals contained a moderate amount of carbohydrate, plenty of protein and a restricted amount of fat. Snacks were given between breakfast and lunch, between lunch and dinner, and at bedtime. The boys received extra snacks, mainly carbohydrate, in the case of considerable feeling of hunger between mealtimes. agent. The amount of total acetone bodies, i.e. the sum of acetoacetate, $\beta$-hydroxybutyrate and free acetone is expressed for blood in $\mu$ mole/l, and for urine in mmole/day. All determinations were done in duplicate. The significance of differences between mean values was determined by Student's $t$-test.

\section{Results}

Blood glucose data from the same sampling hour during two consecutive days were pooled. The same was done with the results on blood acetone bodies.

Table 1. Summary of clinical data on nine diabetic campers

\begin{tabular}{|c|c|c|c|c|c|c|}
\hline $\begin{array}{l}\text { Case } \\
\text { No. }\end{array}$ & $\begin{array}{l}\text { Age } \\
\text { yrs }\end{array}$ & $\begin{array}{l}\text { Weight } \\
\text { kg }\end{array}$ & $\begin{array}{l}\text { Diabetes } \\
\text { duration } \\
\text { yrs }\end{array}$ & stability & $\begin{array}{l}\text { Insulin therapy } \\
\text { preparation }\end{array}$ & $\begin{array}{l}\text { dose at the beginning } \\
\text { of the camp, units }\end{array}$ \\
\hline 1 & 8 & 28 & $13 / 4$ & labile & Lente & 20 \\
\hline 2 & 11 & 42 & $9^{74}$ & hyperlabile & Rapitard & $24+14$ \\
\hline 3 & 10 & 33 & $23 / 4$ & labile & Lente & 24 \\
\hline 4 & 9 & 31 & $21 / 2$ & labile & Rapitard & $20+14$ \\
\hline 5 & 9 & 29 & $3^{2}$ & labile & Lente & 16 \\
\hline 6 & 13 & 52 & 1 & labile & Lente & 44 \\
\hline 7 & 12 & 36 & $41 / 2$ & hyperlabile & Lente & 32 \\
\hline 8 & 11 & 32 & $11 / 4$ & labile & Lente & 26 \\
\hline 9 & 10 & 32 & $4^{74}$ & labile & Lente & 24 \\
\hline Mean & 10.3 & 35 & 3.3 & & & 28.7 \\
\hline
\end{tabular}

The first three camp days were used for introduction into camp life. The campers' physical activity was comparable with that of regular school days. For the purpose of the study, exercise was increased after this initial control period. The boys took part in ball games, marching, running, swimming and were generally encouraged to exercise. The main part of the exercise took place in two sessions before and two sessions after the lunch. Insulin was given at 8 a.m., and in two cases the second dose at 6 p.m. Specimens of capillary blood were taken at $8 \mathrm{a} . \mathrm{m}$. before the administration of insulin, at noon, 3 and 7 p.m., on the 2nd and 3rd, 7 th and 8 th, and 13 th and 14th camp day, and were analysed for glucose and acetone bodies. Blood glucose was determined by the o-toluidine method (HYVÄRINEN and NIKKH bodies, blood was taken into heparinized tubes and deproteinized at once. After centrifugation the supernatant was stored frozen until the determination of acetone bodies was performed. Throughout the duration of the camp; the total daily output of urine of each subject was collected, using three day-time intervals (7 a.m. - noon, noon - 3 p.m.; and 3 p.m. 8 p.m.) and one night-time interval ( 8 p.m. -7 a.m.). Glucosuria was determined by polarimetry, and aliquots of the urine specimens were stored frozen for the quantitative determination of ketonuria. Ketonuria was not recorded on the second and tenth camp day. Blood and urine acetone bodies were measured by the microdistillation procedure of AHOLA and SOMERSALO (1963), in which furfural acts as a colour-trapping
Blood glucose (BG). The mean BG values, mg/ $100 \mathrm{ml} \pm \mathrm{SE}$, are shown in fig. 1. When the samples taken at the same hour of the day were compared, no significant differences were found between mean BG values at the beginning, middle and end of the camping period. The mean BG did not significantly vary within

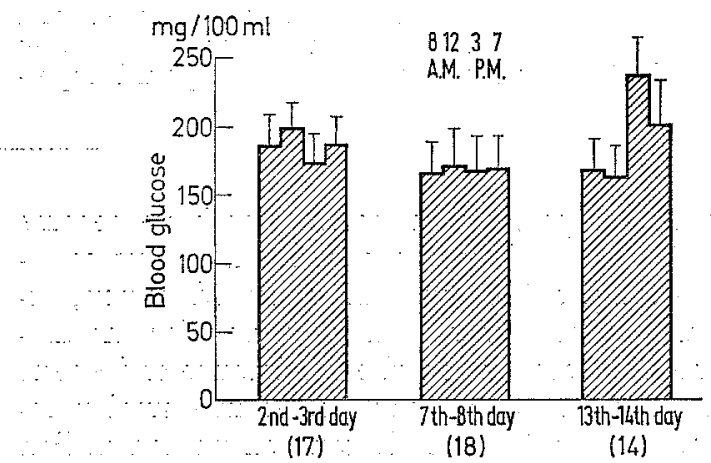

Fig: 1: Mean blood glucose values ( $\mathrm{mg} / 100 \mathrm{ml}) \pm \mathrm{SE}$, during the day in diabetic campers at the beginning, middle and end of the camping period. The figures in bräckets represent the number of specimens, the data of which were pooled for two consecutive days

the day at the beginning and middle of the camping period; but during Camp Days 13 and 14, the 3 p.m. mean BG value of $238 \mathrm{mg} / 100 \mathrm{ml}$ was higher than that at noon $(P<0.05)$. Case 2 had a hypoglycaemic reaction on the fifth camp day at 6 a.m., and he was given glucagon I.M. 
Glucosuria. The mean glucosuria (in $\mathrm{g}, \pm \mathrm{SE}$ ) during the three day-time periods, during the night and per $24 \mathrm{~h}$ is given in table 2 . The average daily excretion of glucose ranged from $7.2 \pm 2.3$ to $53.6 \pm 9.3 \mathrm{~g}$. On six days the nightly glucosuria represented one half or more of the 24-h glucose excretion. There was a considerable day to day variation in the individual camper's glucosuria.

Blood acetone bodies (BAcBo). The mean concentrations of total BAcBo $(\mu$ mole/ $/ 1, \pm \mathrm{SE}$ ) are shown in Fig. 2. The upper limit of normal for total BAcBo, for total BAcBo on each camper from the beginning and end of the camping period were paired, the mean difference was also significant $(P<0.02)$. The decreasing tendency of BAcBo during the camp was seen in the $3 \mathrm{p} . \mathrm{m}$. collections too: the average concentration on Camp Days 13 and 14 was lower than that on the second and third days $(P<0.05)$ and on the seventh and eighth days $(P<0.05)$.

One of the two boys who left for home before the 13th camp day had a morning hyperketonaemia ranging from 560 to $5300 \mu$ mole/l at the beginning and

Table 2. Mean glucosuria $(g \pm S E)$ in diabetic campers during three day-time periods, during the night and per $24 h$

\begin{tabular}{|c|c|c|c|c|c|c|}
\hline Camp day & Number of & Mean glucosuria & $\pm \mathrm{SE})$ & & & \\
\hline & campers & 7 a.m. - noon & Noon -3 p.m. & 3-8 p.m. & 8 p.m. - 7 a.m. & Per $24 \mathrm{~h}$ \\
\hline 2nd & 9 & $0.3 \pm 0.2$ & $0.4 \pm 0.2$ & $1.1 \pm 0.3$ & $5.4 \pm$ & $7.2 \pm 2.3$ \\
\hline 3rd &, & $7.3 \pm 1.9$ & $4.4 \pm 1.9$ & $7.1 \pm 3.6$ & $5.9 \pm$ & $24.7 \pm 6.5$ \\
\hline 4th & ", & $8.0 \pm 2.7$ & $10.2 \pm 2.5$ & $7.0 \pm 2.5$ & $12.6 \pm$ & $37.8 \pm$ \\
\hline 5 th & ," & $9.3 \pm 3.6$ & $4.6 \pm 1.5$ & $9.0 \pm 3.0$ & $5.6 \pm 2.5$ & $28.5 \pm 7.0$ \\
\hline 6 th & , & $6.2 \pm 3.2$ & $4.2 \pm 1.8$ & $13.4 \pm 3.6$ & $22.9 \pm 10.6$ & $46.7 \pm 12$ \\
\hline 7 th & , & $10.6 \pm 3.2$ & $6.9 \pm 3.7$ & $9.5 \pm 3.9$ & $17.8 \pm \quad 7.9$ & $44.8 \pm 14.3$ \\
\hline 8 th & ," & $7.9 \pm 3.1$ & $3.6 \pm 2.4$ & $4.7 \pm 1.4$ & $10.7 \pm$ & $26.9 \pm 9.7$ \\
\hline 9th & , & $3.4 \pm 1.0$ & $4.6 \pm 1.9$ & $4.6 \pm 1.9$ & $23.4 \pm 6.5$ & $36.0 \pm$ \\
\hline 10 th & 7 & $6.2 \pm 3.0$ & $4.6 \pm 2.4$ & $2.1 \pm 1.1$ & $15.9 \pm$ & $28.8 \pm 7.3$ \\
\hline 11th & , & $6.8 \pm 2.0$ & $5.1 \pm 2.4$ & $6.4 \pm 2.5$ & $35.3 \pm$ & $53.6 \pm 9.3$ \\
\hline 12th & , & $5.4 \pm 1.6$ & $7.3 \pm 2.5$ & $6.2 \pm 2.2$ & $12.0 \pm$ & $30.9 \pm 10.8$ \\
\hline 13th & ," & $5.9 \pm 2.6$ & $12.4 \pm 4.1$ & $15.2 \pm 6.4$ & $13.6 \pm \quad 6.4$ & $47.1 \pm 17.3$ \\
\hline $14 \mathrm{th}$ & , & $5.4 \pm 1.8$ & $3.1 \pm 1.3$ & $1.4 \pm 0.5$ & $9.3 \pm 4.2$ & $19.2 \pm 5.6$ \\
\hline
\end{tabular}

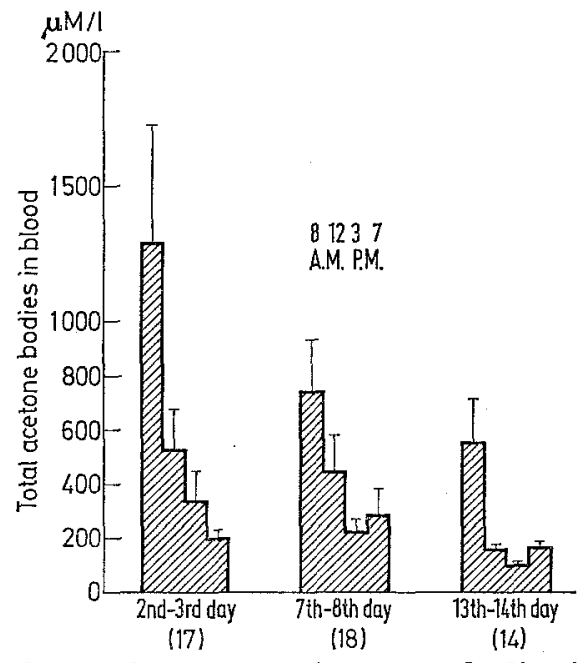

Fig. 2. Mean values for total acetone bodies in blood ( $\mu \mathrm{mole} / \mathrm{l}) \pm \mathrm{SE}$, during the day in diabetic campers at the beginning, middle and end of the camping period. The figures in brackets denote the number of specimens, the data of which were pooled for two consecutive days

determined by the method used in the present study, is $400 \mu \mathrm{mole} / \mathrm{l}$ in this age group ( $\AA$ kERBLoM, 1965). In view of this, it was evident that morning hyperketonaemia occurred during all three sampling periods, although in decreasing degree. The mean BAcBo value at noon on Camp Days 13 and 14 was significantly lower than the corresponding mean value of the second and third camp days $(P<0.02)$. When the noon values
Table 3. The frequency of hyperketonaemia in diabetic campers at the beginning, middle and end of the camping period

Hyperketonaemia $=$ total acetone bodies in blood $>400 \mu$ mole/l. The first figure denotes the number of hyperketonaemic subjects, and the second figure represents the number of cases studied.

\begin{tabular}{llll}
\hline \multicolumn{2}{c}{$\begin{array}{l}\text { Camp days } \\
\text { 2nd-3rd }\end{array}$} & 7th-8th & 13th-14th \\
\hline Time of & & \\
sampling & & & \\
8 a.m. & $6 / 9^{\mathrm{a}}$ & $4 / 9^{\mathrm{a}}$ & $3 / 7$ \\
noon & $3 / 9^{\mathrm{a}}$ & $4 / 9^{\mathrm{a}}$ & $0 / 7$ \\
3 p.m. & $3 / 9^{\mathrm{a}}$ & $2 / 9$ & $0 / 7$ \\
7 p.m. & $2 / 9^{\mathrm{a}}$ & $2 / 9$ & $0 / 7$ \\
\hline
\end{tabular}

a including one camper who left for home before the 13 th camp day.

middle of the camping period. Out of the seven campers who were followed throughout the camp, five boys were hyperketonaemic on the second and third days at $8 \mathrm{a} . \mathrm{m}$. Three of them had morning hyperketonaemia on Camp Days 13 and 14, but in each case the hyperketonaemia was slighter than that at the beginning of the camp. None of the campers showed hyperketonaemia at noon or later in the day at the end of the camping period. Table 3 summarizes the number of hyperketonaemic subjects during the camp.

Correlation of $B G$ with $B A C B o$. A highly significant correlation existed between the 8 a.m. values for BG and for total BAcBo during the second and third, and 
seventh and eighth days $(r=+0.859, P<0.001$ and $r=+0.627, P<0.01$ respectively). The correlation was not present for the values at the end of the camp. At the beginning of the camp there was also a correlation between the noon values for $\mathrm{BG}$ and for $\mathrm{BAcBo}$ $(r=+0.696, P<0.005)$.

Ketonuria. The mean output of total acetone bodies in urine, over collection intervals and per $24 \mathrm{~h}$, and expressed in mmoles is shown in Table 4. The average daily excretion varied from $0.64 \pm 0.14$ to $3.55 \pm 1.47$ mmole/day. On six out of the 11 camp days when ketonuria was recorded, the mean nightly urinary excretion of total acetone bodies was one half or more of the average 24-h excretion. Day to day variations in the amount of ketonuria were observed in most subjects, particularly during the first half of the camp. No correlation was found between 24-h glucosuria and ketonuria. camping period. This partial lack of response was probably due to the lability of the campers' diabetes. The observation that glucosuria did not improve under camp conditions with plenty of exercise, is similar to that of Werr and associates (1967), who found a higher glucosuria in diabetic campers during days of competition compared with a period of "in-group" activity, when competitive activities were avoided. In the authors' opinion, children of the age 9 to 12 years were emotionally so much stimulated by exercise and competitions that the additional exercise did not sufficiently counteract the emotionally-induced hyperglycaemia, whereas younger children's glucosuria decreased due to exercise.

Insulin, diet and exercise form the trio affecting the control of diabetes at the camp as well as in home conditions. The insulin dosage was lowered in the present study only in three boys, and then only to a slight

Table 4. Mean excretion of total acetone bodies in urine of diabetic campers, mmole per three day-time periods, per nigh and per $24 h$

\begin{tabular}{|c|c|c|c|c|c|c|}
\hline \multirow[t]{2}{*}{ Camp day } & \multirow{2}{*}{$\begin{array}{l}\text { Number of } \\
\text { campers }\end{array}$} & \multicolumn{5}{|c|}{ Mean ketonuria, mmole $\pm \mathrm{SE}$} \\
\hline & & 7 a.m. - noon & Noon -3 p.m. & $3-8$ p.m. & 8 p.m. - 7 a.m. & Per $24 \mathrm{~h}$ \\
\hline 3rd & 9 & $0.23 \pm 0.08$ & $0.12 \pm 0.05$ & $0.19 \pm 0.04$ & $1.11 \pm 0.80$ & $1.65 \pm 0.78$ \\
\hline 4th & , & $0.20 \pm 0.09$ & $0.14 \pm 0.02$ & $0.15 \pm 0.05$ & $0.69 \pm 0.31$ & $1.18 \pm 0.37$ \\
\hline ath & $"$ & $0.23 \pm 0.08$ & $0.18 \pm 0.07$ & $0.21 \pm 0.10$ & $0.19 \pm 0.04$ & $0.81 \pm 0.26$ \\
\hline 6th & 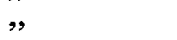 & $0.50 \pm 0.24$ & $0.09 \pm 0.02$ & $0.10 \pm 0.02$ & $0.28 \pm 0.04$ & $0.97 \pm 0.23$ \\
\hline 7 th & ", & $0.40 \pm 0.18$ & $0.14 \pm 0.02$ & $0.25 \pm 0.10$ & $2.76 \pm 1.30$ & $3.55 \pm 1.47$ \\
\hline 8 th & 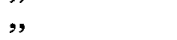 & $1.29 \pm 0.97$ & $0.10 \pm 0.03$ & $0.08 \pm 0.01$ & $0.29 \pm 0.09$ & $1.76 \pm 0.99$ \\
\hline 9th & ", & $0.11 \pm 0.04$ & $0.08 \pm 0.01$ & $0.07 \pm 0.01$ & $0.38 \pm 0.09$ & $0.64 \pm 0.14$ \\
\hline 10th & 7 & & & not recorded & & \\
\hline 11 th & ," & $0.11 \pm 0.05$ & $0.06 \pm 0.02$ & $0.07 \pm 0.01$ & $1.09 \pm 0.63$ & $1.33 \pm 0.65$ \\
\hline 12 th & ," & $0.07 \pm 0.01$ & $0.08 \pm 0.02$ & $0.12 \pm 0.02$ & $0.48 \pm 0.18$ & $0.75 \pm 0.18$ \\
\hline 13th & ", & $0.26 \pm 0.15$ & $0.14 \pm 0.04$ & $0.13 \pm 0.03$ & $0.42 \mp 0.15$ & $0.95 \pm 0.29$ \\
\hline 14th & ", & $0.37 \pm 0.27$ & $0.09 \pm 0.02$ & $0.05 \pm 0.01$ & $0.42 \pm 0.11$ & $0.93 \pm 0.33$ \\
\hline
\end{tabular}

\section{Discussion}

The initial control of the campers' diabetes was in most cases not optimal. At the beginning of the camp the mean $B G$ values varied during the day between 174 and $199 \mathrm{mg} / 100 \mathrm{ml}$. Initially there was also considerable morning hyperketonaemia, typical for juvenile diabetics who are poorly controlled.

The control of diabetes improved during the camp when judged from the occurence of BAcBo; notably a decrease in the frequency and magnitude of morning hyperketonaemia. The reduction in morning and noon hyperketonaemia during the camp was also seen in the disappearance of the correlation between $B G$ and BAcBo towards the end of the camp. Hypoglycaemic reactions were not observed during the night. Undetected nocturnal hypoglycaemic episodes might never. theless have occurred in some campers due to a prolonged effect of Lente insulin. Such episodes could have been in part responsible for morning hyperketonaemia.

The overall control of diabetes did not, however, improve during the two weeks camp, as seen from the high mean BG levels and glucosuria throughout the degree. Aroidance of hypoglycaemic reactions was usually achieved by adjusting the size of the meals and providing extra snacks. STRUWE (1961) reported that juvenile diabetics had to be given $50 \%$ more carbohydrate during a camp, in order to maintain the diabetic control when the dose of insulin remained unchanged. It was difficult to compare the campers' previous diet at home with the camp diet. But at least in some cases there was evidence of uncontrolled diet at home, and in these campers the supervised camp diet perhaps contributed to a somewhat better control of diabetes.

Exercise at camp after the initial control days most likely exceeded that of school days. The question of the effect of exercise on the metabolism of acetone bodies in insulin-treated diabetics deserves attention. WILLIAMS (1961) suggested that exercise causes promoted utilization of acetone bodies. In the author's previous study ( $\AA$ KHRBLOM, 1965), short-term effects of muscular exercise on $\mathrm{BAcBo}$ in juvenile diabetios were discussed. Subjects with pre-exercise morning hyperketonaemia usually showed a decrease in BAcBo to normal level after exercise. However, definite conclusions could not 
be drawn whether the decreases of $\mathrm{BAcBo}$ were due to exercise or instlin. Exercise was not considered to be harmful in the short term to labile, hyperketonaemiaprone diabetics, provided they are subjectively well and not acidotic. The results of the present study, comprising observations from a longer period confirm this view. The diabetic control improved during increased muscular exercise as regards the levels of BAcBo. However, it must be recognized that it was difficult to judge in some cases how much this improvement was due to exercise and how much to the diet.

With regard to this study, the importance of an adequate insulin dosage, a proper diet and avoidance of hypoglycaemic reactions during camp conditions remains essential.

Acknowledgements: The author expresses his warm thanks to Docent HirkKa Hrekkala, M.D. for her help in the planning of the study and for criticism of the manuscript, to ToM AHOLA, M.Se. for continued help in laboratory matters, and to Miss Eva Forsselu for excellent technical assistance. The co-operation of the camp staff of the Finnish Diabetes Association is acknowledged.

\section{References}

Ahola, T., and O. Somersalo: Microdetermination of acetone bodies in blood and urine. Ann. Med. exp. Fenn. 41, 237-246 (1963).

ÅkfRBLom, H. : Blood acetone bodies of juvenile diabetics after exercise. Ann. Paediat. Fenn. 11, suppl. 25 (1965).

Handelsmair, M.B., W.C. Loughtin, and G.J. FriedMAN: Management of juvenile diabetes at Camp Nyda. A summary of methods and results based on the experiences in 1957 and 1958. Amer. J. clin. Nutr. 9, 583595 (1961).

HyvärINEN, A., and E.A. NזKkLÏ: Specific determination of blood glucose with o-toluidine. Clin. chim. Acta $7,140-143(1962)$.

STRUwe, F.E. : Das Stoffwechselverhalten kindlicher Diabetiker in Ferienlagern. Arch. Kinderheilk. 163, 35-47 (1961).

WeIn, W.B., M.B. Sussmat, and A.J. Cratr : Social patterns and diabetic glucosuria. Amer. J. Dis. Child. 113, $454-460$ (1967).

Williams, R.H.: Ketosis. Arch. intern. Med. 107, 69-74 (1961).

Dr. H.K. ÅKERBLOM

The Children's Hospital

University of Helsinki

11 Stenbäck Street.

Helsinki 29

Finland 